\title{
FAMI72A expression in circulating tumor cells for prediction of high-risk subgroups of colorectal cancer [Retraction]
}

Xu C, Zhang C, Wang H, Yang H, Li G, Fei Z, Li W. FAM172A expression in circulating tumor cells for prediction of high-risk subgroups of colorectal cancer. OncoTargets and Therapy. 2017;10:1933-1939.

The authors of this paper have advised Dove Medical Press that a collaborating laboratory had originally generated the key technology and data that was used in the published study. The authors did not have approval to use the data which has violated the rights of the collaborating lab. The authors are also in breach of the Dove Medical Press Terms of Publication. The authors seek to Retract the published paper.
OncoTargets and Therapy

\section{Publish your work in this journal}

OncoTargets and Therapy is an international, peer-reviewed, open access journal focusing on the pathological basis of all cancers, potential targets for therapy and treatment protocols employed to improve the management of cancer patients. The journal also focuses on the impact of management programs and new therapeutic agents and protocols on

\section{Dovepress}

patient perspectives such as quality of life, adherence and satisfaction. The manuscript management system is completely online and includes a very quick and fair peer-review system, which is all easy to use. Visit http://www.dovepress.com/testimonials.php to read real quotes from published authors. 